\title{
“Tiesību tikt aizmirstam" piemērošanas un izpratnes problēmas Latvijā
}

\author{
Svetlana Sitņikova \\ Rìgas Stradiña universitāte
}

\section{Kopsavilkums}

"Tiesības tikt aizmirstam" ir samērā jauns tiesību institūts, kura aktualizēšanas priekšnosacījums ir tehnologiju attīstība un globalizācija, kas šobrīd ḷaj padarìt informāciju, tostarp arī personas datus un sensitīvus datus, publiski pieejamu visā pasaulē. Iepriekšminētais rada nepieciešamību veicināt personas datu aizsardzību.

"Tiesības tikt aizmirstam" īpaši tika aktualizētas saistībā ar Eiropas Savienības tiesas lēmumu lietā C-131/12 Google Spain SL, Google Inc. pret Agencia de Protección de Datos, Mario Costeja González (t. s. Google v Spain lieta). Arī Eiropas Cilvēktiesību tiesa saskaras ar jaunām koncepcijām, no kurām viena ir "tiesības tikt aizmirstam".

Veicot pētijumu, tika gūtas šādas atziṇas: Latvijas Republikas normatīvajos aktos paredzētie aizsardzības līdzekḷi, atbildība un sankcijas tikai dą̣ēji veicina "tiesību tikt aizmirstam" ievērošanu. Pētỉjumā iesaistìtās valsts iestādes neapzinās ar fizisko personu datu apstrādi saistītos potenciālos riskus un tos novērsa (veica nepieciešamās izmaiṇas datu apstrādes sistēmās) tikai pēc privātpersonas(-u) iesnieguma saṇemšanas. Šì iemesla dẹl, lai stiprinātu Latvijas iedzìvotāju uzticēšanos valsts iestādēm jautājumā par tiešsaistē atrodamiem datiem un panāktu jaunu pakalpojumu, tostarp arī publisko e-pārvaldības pakalpojumu izmantošanu, tādējādi sekmējot ekonomikas izaugsmi, valsts iestādēm ir jāpārskata sava prakse saistībā ar personas datu apstrādi un pieejamību tiešsaistē.

Atslēgvārdi: Direktīva 95/46/EK, Fizisko personu datu aizsardzības likums, fizisko personu datu apstrāde, "tiesības tikt aizmirstam", personas dati, personas datu aizsardzība, Vispārīgā datu aizsardzības regula. 


\section{levads}

2012. gada 25. janvārī Eiropas Komisija ierosināja Eiropas Savienības datu aizsardzības noteikumu radikālu reformu, lai padarītu tos atbilstošus 21. gadsimtam, t. i., lai nostiprinātu tiesības uz privātumu tiešsaistē un stimulētu Eiropas digitālo ekonomiku. Pamantojums tam ir ne tikai tas, ka "informācijas apstrādes iespēju attīstỉbas ātrums apsteidz to normatìvu izstrādi, kas šos procesus regulē” [21, 5], bet arī tas, ka 27 ES dalībvalstis Eiropas Padomes un Padomes Direktīvas 95/46/EK par personu aizsardzību attiecībā uz personas datu apstrādi un šādu datu brīvu apriti noteikumus ir īstenojušas atšḳirīgi. Viena no galvenajām ar reformu piedāvātajām izmaiṇām ir "tiesības tikt aizmirstam”, kas palīdzēs cilvēkiem labāk pārvaldīt datu aizsardzības riskus tiešsaistē: cilvēki varēs dzēst savus datus, ja nebūs likumīgu iemeslu tos saglabāt.

Raksta mērḳis - izpētīt ar "tiesību tikt aizmirstam” izpratni un realizāciju saistītas īpatnības un iespējamās problēmas Latvijas Republikā (turpmāk tekstā LR).

Materiāls un metodes - attālinātās, individuālās, strukturētās intervijas ar lielāko ziṇu portālu Tvnet.lv, Latvijā vienīgo vietējo sociālo tīklu vietni Draugiem.lv, Datu valsts inspekciju, LR Tiesībsargu, Augstāko tiesu un Tiesu administrāciju.

\section{“Tiesību tikt aizmirstam” izmantošana un ievērošana}

2011. gadā, tieši pirms Eiropas Komisija ierosināja visaptverošu datu aizsardzības noteikumu reformu, lai palielinātu lietotāju iespējas kontrolēt savus datus un samazinātu izmaksas uzṇēmumiem, visās ES dalībvalstīs tika veikts Eurobarometer pētījums. Pētījuma laikā tiešajās intervijās tika aptaujāti 1000 Latvijas iedzìvotāju. Iegūtie dati liecina, ka 47\% Latvijas interneta lietotāju iegādājas preces vai pakalpojumus tiešsaistē (piemēram, ceḷojumus un brīvdienu paketes, apgeērbu, grāmatas, biḷetes, filmas, mūzikas ierakstus, programmatūru, pārtiku), 73\% izmanto sociālās tīklošanas vietnes, 56\% izmanto interneta vietnes, lai apmainītos ar fotogrāfijām, videofailiem un filmām [4].

Ievērības cienīgs ir aptaujas rezultātu salīdzinājums, vērtējot Latvijas iedzīvotāju informētību un uzskatus par to, cik liela ir vinu kontrole pār savu informāciju, ko cilvēki atklāja tiešsaistē. Uz jautājumu "Kā Jums šķiet, cik lielas ir Jūsu iespējas kontrolēt informāciju, ko esat atklājis/-usi sociālās tīklošanas vietnēs, un/vai informācijas apmaiṇas vietnēs ir iespējas, piemēram, šo informāciju mainīt, dzēst vai labot?" 17\% Latvijas sociālo tîklu lietotāju, kas tajos atklāja savu informāciju, atbildēja, ka tiem ir pilnīga kontrole pār savu informāciju, 54\% norādīja, ka viṇiem ir daḷēja kontrole pār savu informāciju, bet $27 \%$ atzīmēja, ka viņiem nav nekādu kontroles iespēju (sk. 1. att.).

Sniedzot atbildes uz šo pašu jautājumu, 26\% ES respondentu atbildēja, ka viniem ir pilnīga kontrole pār savu informāciju, bet $20 \%$ ES respondentu norādīja, ka viniem nav nekādu kontroles iespēju pār savu informāciju [4]. Tas nozīmē, ka ES iedzīvotāii ir vidēji vairāk informēti par savām iespējām kontrolēt informāciju par sevi nekā Latvijas iedzīvotāji. 
Atbildot uz jautājumu "Kā Jums šḳiet, cik lielas iespējas Jums ir kontrolēt informāciju, ko esat atklājis/-usi sociālās tīklošanas vietnēs, un/vai informācijas apmaiṇas vietnēs ir iespējas, piemēram, šo informāciju mainīt, dzēst vai labot?", 12\% Latvijas tiešsaistes pircēju, kas tiešsaistē atklājuši savu informāciju, uzskata, ka viṇiem ir pilnīga kontrole pār savu informāciju, 50\% domā, ka viṇiem ir daḷejja kontrole pār savu informāciju, bet 36\% ir pārliecināti, ka viṇiem nav nekādu kontroles iespēju pār savu informāciju (sk. 2. att.).

Veiktā pētỉjuma rezultāti rāda, ka $27 \%$ Lat vijas sociālo tīklu lietotāju nav informēti par iespējām kontrolēt (mainìt, dzēst vai labot) informāciju par sevi, ko viṇi ir atklājuši sociālās tīklošanas vietnēs. Savukārt 36\% Latvijas tiešsaistes pircēju uzskata, ka viṇiem nav pilnīgi nekādu kontroles iespēju (mainìt, dzēst vai labot) pār informāciju, ko viṇi ir atklājuši sociālās tīklošanas vietnēs un/vai informācijas apmaiņas vietnēs. Tādējādi ir maz ticams, ka personas, kuras šādi ir atbildējušas uz pētījuma jautājumiem, spēj izmantot savas "tiesības tikt aizmirstam".

Pēc 2014. gada 13. maijā publicētā Eiropas Savienības tiesas sprieduma lietā C-131/12 un 2014. gada 29. maijā Google tā juridiskajai nodaḷai pakḷautās īpašās komisijas izveidošanas līdz 2016. gada 15. janvārim Google no Latvijas tika saṇemts 1421 pieprasijjums par datu dzēšanu un Google ir novērtējusi 6176 tīmekḷa adreses. No Lietuvas tika saṇemti 1894 pieprasījumi un novērtētas 7254 tīmekḷa adreses, savukārt no Igaunijas tika saṇemti 2695 pieprasījumi un novērtētas 8784 tīmekḷa adreses [6]. Salīdzinot trīs Baltijas valstu datus, var secināt, ka no Latvijas ir vismazāk pieteikumu.

N̦emot vērā, ka visās trīs Baltijas valstīs pielāgotā Google meklētājprogramma (google.lv, google.lt, google.ee) un tās globālā versija (google.com) ir apmeklētākās interneta vietnes [2], kā arī iepriekšminēto pieprasījumu skaitu, ko Google ir saṇēmusi no Latvijas, Lietuvas un Igaunijas, šì darba autore izvirza divas hipotēzes par situāciju Latvijā:

1) personas Latvijā nav pietiekami informētas par savām "tiesībām tikt aizmirstām";

2) Latvijā personas tiesības uz privātās dzīves neaizskaramību ir ievērotas un labi aizsargātas, tāpēc personām nav nepieciešams vērsties Google, lai izmantotu savas "tiesības tikt aizmirstām".

Lai atbildētu uz jautājumu, kura no minētajām hipotēzēm ir pareiza, būtu nepieciešams ieskatīties 2011. gada Eurobarometer pētījuma datos par Lietuvu un Igauniju. Salīdzinot ar Latvijas $27 \%$ sociālo tīklu lietotāju, kuri nav informēti par iespējām kontrolēt (mainīt, dzēst vai labot) informāciju par sevi, ko viṇi ir atklājuši sociālās tīklošanas vietnēs, šādu personu īpatsvars Lietuvā ir 13\% un Igaunijā 15\% (sk. 1. att.) [4].

Savukārt, salīdzinot ar 36\% Latvijas tiešsaistes pircēju, kuri uzskata, ka viṇiem nav pilnīgi nekādu kontroles iespēju (mainīt, dzēst vai labot) pār informāciju, ko viṇi ir atklājuši sociālās tīklošanas vietnēs un/vai informācijas apmaiṇas vietnēs, Lietuvā un Igaunijā šādu personu îpatsvars ir attiecīgi 18\% un 23\% no aptaujāto skaita (sk. 2. att.) [4]. 
Svetlana Sitņikova. “Tiesību tikt aizmirstam” piemērošanas un izpratnes problēmas Latvijā

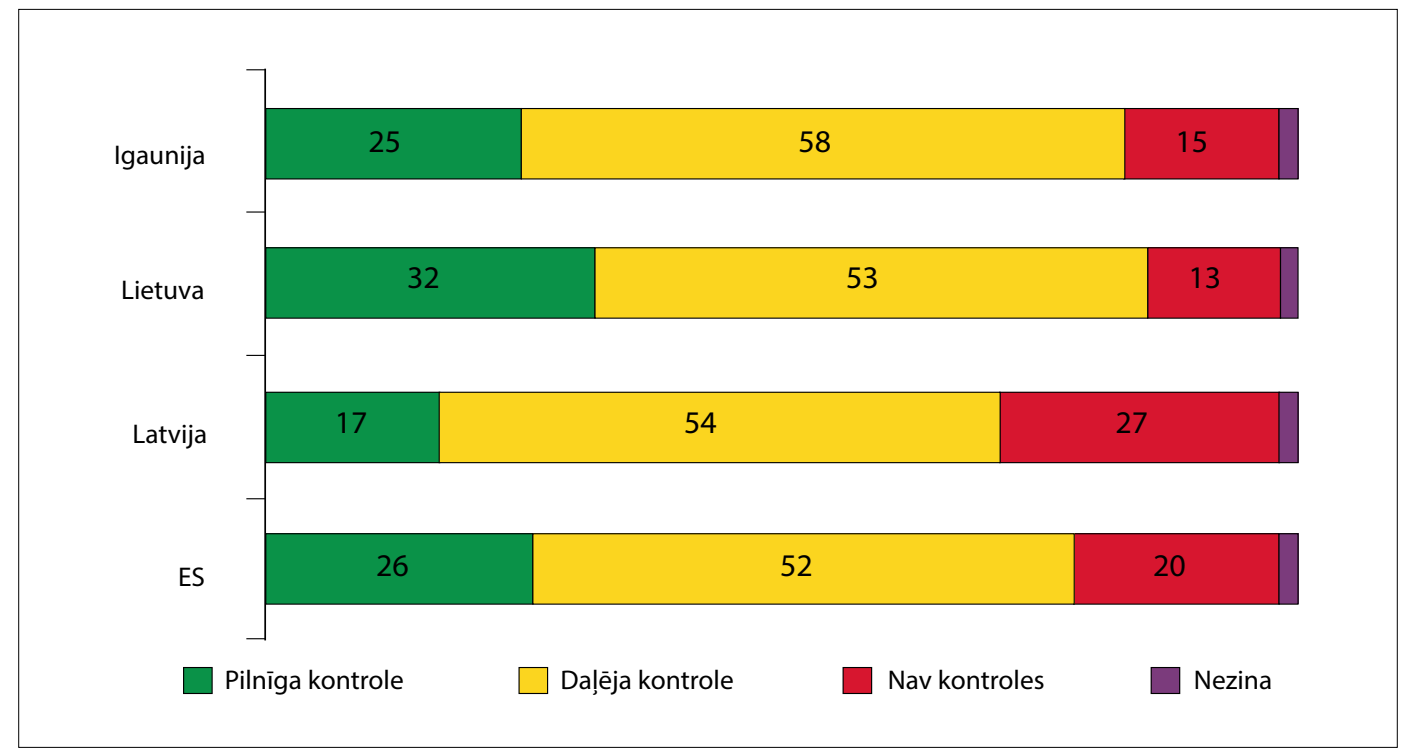

1. attēls. Iedzīvotāju informētỉba par iespējām kontrolēt informāciju tiešsaistē

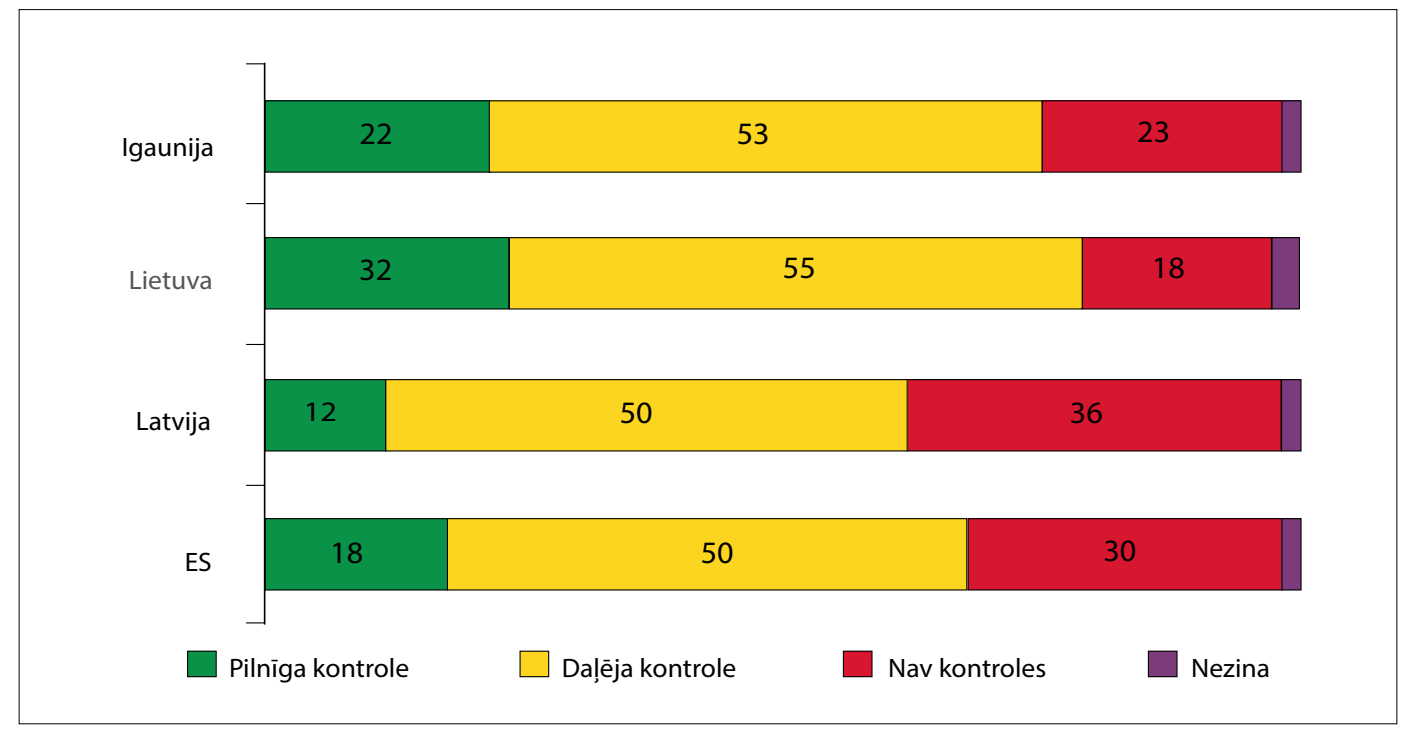

2. attēls. Kontrole pār savu informāciju tiešsaistē, pēc iedzīvotāju domām 
Aplūkojot datus, var secināt, ka personas Latvijā nav pietiekami informētas par savām "tiesībām tikt aizmirstām" un tās arī neizmanto. Iznākumā, pamatojoties uz spēkā esošajām tiesību normām, kas paredzētas gan Direktīvā 95/46/EK, gan LR Fizisko personu datu aizsardzības likumā (turpmāk tekstā FPDAL), par "tiesību tikt aizmirstam" ievērošanu atbildīgām kompānijām (iestādēm, firmām u. c.) šìs tiesības nav jāievēro, ja datu subjekts tajās nav iesniedzis sūdzību par savu tiesību pārkāpumu.

Kaut gan Latvijā personas nav pietiekami informētas par savām "tiesībām tikt aizmirstām”, 2015. gada 29. aprīlī intervijā ar LR Augstāko tiesu saṇemtā informācija liecina, ka pirms 2014. gada 13. maija LR Augstākā tiesa bija saṇēmusi kādas lietas dalībnieku sūdzības, ka viṇu vārds ir bijis atrodams Tiesas kalendārā pēc tam, kad Google.lv mājaslapā ierakstīts konkrētais vārds. N̦emot vērā šĩs sūdzības un mēǵinot novērst šādu situāciju atkārtošanos nākotnē, Augstākā tiesa novērsa iespēju informācijai nokḷūt Google mājaslapā - Augstākās tiesas mājaslapas administrators Google rīkā 2014. gada sākumā iesniedza saites, kuras dzēst no Google datubāzes, lai Tiesas kalendārā pieejamā informācija par tiesā izskatāmajām lietām nebūtu saistìta ar Google meklētāju [10].

Augstākās tiesas 2014. gada sākumā veiktie pasākumi, pamatojoties uz privātpersonas(-u) iesniegumu, liecina par faktu, ka līdz tam privātpersonas nebija vērsušās Augstākajā tiesā un netika izmantojušas savas "tiesības tikt aizmirstām". Savukārt Augstākajai tiesai, kas ir datu pārzinis ar likumā noteiktiem pienākumiem, līdz brīdim, kamēr privātpersonas nebija izmantojušas savas "tiesības tikt aizmirstām" vērsušās pie tās ar lūgumu izbeigt savu personas datu apstrādi -, nebija pienākums šīs tiesības ievērot.

Pēc privātpersonu saṇemtajiem iesniegumiem 2013. gada 18. decembrī Augstākās tiesas priekšsēdētājs apstiprināja kārtību "Informācijas sagatavošanas un publicēšanas kārtība Augstākās tiesas mājaslapā internetā un iekštīklā” [10]. Savukārt Direktīva 95/46/ EK stājās spēkā 1995. gada 24. oktobrī, Latvija ir ES dalībvalsts kopš 2004. gada 1. maija, bet tikai 2014. gada sakumā pēc datu subjekta iesnieguma Augstākās tiesas mājaslapā tika mainīts tiesu informācijas publicēšanas veids un tika noteikti ierobežojumi attiecībā uz Google meklētāju. Rezultātā tika ievērotas arī citu personu tiesības uz privātās dzīves neaizskaramību. Pēc 2014. gada 13. maija Augstākajā tiesā netika saṇemti pieprasijjumi no privātpersonām ar lūgumu, pamatojoties uz FPDAL 16. panta pirmajā dạ̣ā noteiktajām datu subjekta tiesībām, papildināt, izlabot, pārtraukt datu apstrādi vai iznīcināt datus, kurus iestāde publicē tīmekḷa vietnē www.at.gov.lv [10]. Šādai iniciatīvai, pēc raksta autores domām, tomēr būtu jānāk nevis no privātpersonām, kuras, aizsargājot tiesības uz privāto dzīvi, izmanto savas "tiesības tikt aizmirstām", bet no valsts iestādēm, kuru uzdevumos ietilpst noteikta privātpersonu datu aizsardzība un privātās dzīves neaizskaramība.

Šajā situācijā nevar apgalvot, ka citu personu "tiesības tikt aizmirstām", tām pašām šīs tiesības neizmantojot, tika ievērotas, nodrošinot FPDAL 10. panta pirmās dal̦as 3. punktā noteikto personas datu glabāšanas veidu, kas datu subjektu l̦auj identificēt 
konkrētajā laikposmā, kurš nepārsniedz paredzētajam datu apstrādes mērḳim noteikto laikposmu, jo no FPDAL, Direktīvas 95/46/EK, kā arī no EST sprieduma lietā C-131/12 izriet, ka tikai pati persona var izmantot savas "tiesības tikt aizmirstai" un, tikai personai šìs tiesības izmantojot, datu pārzinim ir pienākums šis tiesības ievērot.

Savukārt Tiesu administrācija bija saṇēmusi vienu personas pieprasījumu saistībā ar FPDAL 16. panta pirmajā daḷā noteiktajām tiesībām pirms 2014. gada 13. maija EST sprieduma lietā C-131/12 un vienu personas pieprasījumu pèc šì datuma [8]. Tiesu administrācija apmierināja abu personu pieprasījumus par datu labošanu saistỉbā ar FPDAL 16. panta pirmajā daḷā noteiktajām tiesībām, kurus tā saṇēma pirms un pēc 2014. gada 13. maija EST sprieduma lietā C-131/12 [8]. Tiesu administrācijas veiktās izmaiṇas e-pakalpojumu sadal̦ā "Tiesvedības gaitā", kur, ievadot lietas numuru vai tiesas pavēstes numuru, jebkura persona var iegūt datus par interesējošās lietas tiesvedības gaitu, vairs nav redzama informācija par tiesvedībā iesaistīto pušu vārdiem un uzvārdiem, kā arī uzṇēmumu nosaukumi. Tādējādi arī šajā gadījumā valsts iestāde ir izpildījusi valsts pozitīvo pienākumu veikt pasākumus, lai nodrošinātu privātās dzīves neaizskaramību, nevis ievērojusi personu "tiesības tikt aizmirstām".

Pēc Vispārīgās datu aizsardzības regulas stāšanās spēkā, pamatojoties uz tās 73. panta trešo daļu, neatkarīgi no datu subjekta sūdzības jebkurai struktūrai, organizācijai vai asociācijai, kuras mērḳis ir aizsargāt datu subjektu tiesības un intereses saistībā ar to datu aizsardzỉbu un kura ir izveidota saskaṇā ar dalïbvalsts tiesību aktiem, būs tiesības iesniegt sūdzību jebkuras dalībvalsts uzraudzības iestādē, ja tā uzskata, ka ir noticis personas datu aizsardzības pārkāpums. Tādējādi tiktu aizsargātas to personu intereses, kuras pašas kaut kādu iemeslu dẹḷ savas "tiesības tikt aizmirstām" izmantot nevar.

Šĩ struktūra Latvijā ir LR Tiesībsargs, kura uzdevumos, kā jau tika minēts, ietilpst arī tiesību uz privātās un gimenes dzīves neaizskaramību aizsardzība un veicināšana [17]. 2014. gada 30. decembrī pieteikumā LR Satversmes tiesai Tiesībsargs norādīja, ka iebilst pret Uzturlīdzekḷu garantiju fonda parādnieku personas datu publiskošanu fonda administrācijas mājaslapā un ka apstrīēetā norma neatbilst Satversmes 96. panta vārdiem "Ikvienam ir tiesības uz privātās dzìves [..] neaizskaramību" [18]. Šì ir LR Tiesībsarga pagaidām vienīgā paustā iniciatīva personas datu aizsardzības jomā elektroniskajā vidē, kuru raksta autore ir spējusi atrast LR Tiesībsarga 2011.-2014. gada ziṇojumos un kas nākotnē potenciāli var tikt saistīta ar personu "tiesībām tikt aizmirstām".

K. Vilka rakstā "Bērna tiesību uz privāto dzīvi aizsardzība interneta vidē", kas bija publicēts starptautiskajā zinātniski praktiskajā konferencē "Transformācijas process tiesībās, reǵionālajā ekonomikā un ekonomiskajā politikā", ir sniegusi pētījuma rezultātus. Tā mērkisis bija "aktualizēt vienu no bērnu tiesību aizsardzības aspektiem kā aizsargāt bērna tiesības uz privāto dzīvi un personas datu aizsardzību interneta vidē laikā, kad žurnālisti ne vienmēr izvērtē savas darbības sekas, savukārt bērniem bieži vien ir nepietiekama informācija par iespējām aizsargāt savas tiesības" [23]. 
Pētijuma ietvaros K. Vilka izvērtējusi publikācijas un videofailus, kas satur informāciju par Iḷguciema cietuma Nepilngadīgo nodạı un Bērna un mātes nodạıu, Cēsu audzināšanas iestādes nepilngadīgajiem, kas ir cietuši vai apsūdzēti kriminālprocesā, kā arī intervējusi Iḷguciema cietuma Nepilngadīgo audzināšanas nodạ̣as bijušās ieslodzìtās $[23,165]$. K. Vilka norāda, ka viṇai "radās pārliecība, ka ir situācijas, kad ir aizskartas bērna tiesības uz privāto dzīvi un arī personas datu aizsardzība interneta vidē Latvijā," turklāt "nepietiekama uzmanība tiek pievērsta bērna tiesību uz privāto dzīvi un personas datu aizsardzībai interneta vidē Latvijā un netiek novērtētas pārkāpuma sekas" [23, 166]. "Nepilngadīgie pēc atbrīvošanas no ieslodzỉjuma nereti nonāk situācijās, kad viṇu fotogrāfijas ir atrodamas interneta portālos, liecinot par viṇu atrašanos ieslodzījumā." [23, 166] Kaut gan "nepilngadīgās ieslodzījumā ir izcietušas sodu, tomēr brīvībā šis sods turpinās kā kauna sajūta par faktu, ka teorētiski katrs var uzzināt par viṇu cietumā pavadìto laiku" [23, 168].

Jāuzsver, ka personas datus atḷauts apstrādāt tikai FPDAL 7. pantā minēto nosacījumu iestāšanās gadījumā. K. Vilkas aprakstītajā situācijā neviens no šiem nosacỉjumiem nav iestājies, tāpēc arī FPDAL 7. pantā noteiktais nav ievērots. Pēc iepriekšminētās (2012. gadā Latvijā pastāvošās) situācijas nevar noteikt, vai tiek ievērots FPDAL 16. panta pirmās daḷas otrajā teikumā noteiktais pārziṇa pienākums nekavējoties novērst personas datu, kas ir nepilnīgi, novecojuši, nepatiesi, pretlikumīgi apstrādāti vai arī vairs nav nepieciešami datu vākšanas mērḳim, nepilnības vai pārkāpumus un par to paziṇot trešajām personām, kas iepriekš ir saṇēmušas apstrādātos datus, jo šāds pienākums iestājas tikai un vienīgi, ja to var pamatot datu subjekts. Tieši šādā veidā būtu jāizpaužas "tiesībām tikt aizmirstam".

Taču skaidrs ir fakts - ja personas datu aizsardzības un "tiesību tikt aizmirstam" normas tiktu ievērotas, tad nepastāvētu iepriekšminētās situācijas un K. Vilka raksta secinājumos nevis aicinātu Ieslodzījuma vietu pārvaldi informēt žurnālistus par aizliegumu fotografēt un filmēt bērnus ieslodzījuma vietās, bet gan mudinātu bijušās ieslodzìtās izmantot FPDAL 16. panta pirmajā dạ̦ā noteiktās "tiesības tikt aizmirstam", t. i., tiesības pieprasīt, lai vinu personas datus pārtrauc apstrādāt vai iznīcina tos, jo tie vairs nav nepieciešami datu vākšanas mērḳim. Tātad aktīvi darboties, isstenojot normas pieškirtās iespējas, kas ir tiesību normas izmantošana. Tad datu pārzinim radīsies pienākums nekavējoties novērst šo nepilnību vai pārkāpumu un par to paziṇot trešajām personām, kas iepriekš ir saṇēmušas apstrādātos datus. Tādējādi, balstoties uz likumā noteikto pienākumu, datu pārzinis ievēros bijušo ieslodzìto "tiesības tikt aizmirstām" un vinu sods neturpināsies brīīibā. 


\section{“Tiesību tikt aizmirstam” izpildīšana}

Pēc šĩ raksta autores domām, tieši tas, ka likumā "Par presi un citiem masu informācijas līdzekḷiem” un Elektronisko plašsaziñas līdzekḷu likumā nav paredzēta personas "tiesības tikt aizmirstai" ievērošana, kas ir noteikta FPDAL 16. panta pirmajā daḷā un paredzēta Direktīvas 95/46/EK 12. panta b) punktā, var kavēt "tiesību tikt aizmirstam" izpildīšanu Latvijā.

Pamatojoties uz Eiropas Padomes Parlamentārās asamblejas Rezolūcijā 428 (1970) iekḷautās Deklarācijas par masu komunikācijas medijiem un cilvēktiesībām C daḷas otrajā paragrāfā definētajām tiesībām uz privātumu, Eiropas Padomes Parlamentārās asamblejas Rezolūcijas 1165 (1998) "Par tiesībām uz privātumu" 5. paragrāfā noteikto, ka tiesības kontrolēt savus datus pievienojamas tiesību uz privātumu definīcijai, kā arī Rezolūcijā 1165 (1998) Eiropas Padomes Asamblejas noteikto uzdevumu dalībvalstīm nodrošināt nacionālās likumdošanas ietvaros efektīvas privātuma aizsardzības garantijas, tostarp nodrošināt aizskartās personas tiesības civiltiesiskā kārtībā prasīt iespējamo nodarītā kaitējuma atlīdzību par neatḷauto iejaukšanos personas privātajā dzīvē, un masu mediju pārstāvjiem uzlikt atbildību par tādu materiālu publiskošanu, kas pārkāpj personas privātās dzīves neaizskaramību, var secināt, ka Latvijas likumdevējam likumā "Par presi un citiem masu informācijas līdzekḷiem" un Elektronisko plašsaziṇas līdzekḷ likumā būtu jāparedz personas "tiesības tikt aizmirstai" nodrošināšana.

Likumdevējam normatīvajos aktos, nosakot morālā kaitējuma apmēru, gadījumos, kad personai ir liegtas tiesības kontrolēt savus datus, tātad liegtas tās "tiesības tikt aizmirstai", būtu jāvadās pēc ECT nostājas, kuru tā pauda lietas "Armoniene pret Lietuvu" 46. punktā, nosakot nepieciešamos pasākumus, lai nodrošinātu privātuma aizsardzību. Valsts var ṇemt vērā noteiktus finansiālus standartus, kas balstīti uz valsts ekonomisko situāciju, valsts pat var ierobežot morālā kaitējuma atlīdzības apmēru, taču šādi ierobežojumi nedrīkst ietekmēt personas privātuma vērtību tā, ka tādējādi Eiropas Cilvēktiesību konvencijas 8. pantā nostiprinātās tiesības zaudētu to efektīvo saturu [5].

Administratīvā pārkāpumu kodeksā (turpmāk tekstā APK) paredzētā atbildība par 204. ${ }^{9}$ panta (fiziskās personas datu apstrāde bez registrēšanas), $204 .{ }^{10}$ panta (informācijas nesniegšana Datu valsts inspekcijai) un 204. ${ }^{11}$ panta (personu neakreditēšanās Datu valsts inspekcijā) neievērošanu, pēc šì darba autores domām, nekādi nesekmē "tiesību tikt aizmirstam" izpildīšanu tā vienkāršã iemesla dēl, ka APK par to neizpildīšanu nav paredzēta administratīvā atbildība.

Lìdzīgi var teikt par Krimināllikuma (turpmāk tekstā - KL) 145. panta pirmajā dạ̦ā paredzēto kriminālatbildību par nelikumīgām darbībām ar fiziskās personas datiem, ja ar to radīts būtisks kaitējums. Lai gan likuma "Par Krimināllikuma spēkā stāšanās un piemērošanas kārtību” 23. panta trešā daḷa nosaka, ka ar likumu aizsargāto interešu apdraudējuma kritērijus var noteikt šã likuma pielikumos, šì darba autore nav atradusi ar nelikumīgām darbībām ar fiziskās personas datiem saistītus kritērijus. Tiesa gan, Saeimā 2015. gada 9. aprīlī ir pieṇemti grozījumi KL 23. pantā. 
KL 145. panta otrajā daḷā paredzētā atbildība par nelikumīgām darbībām ar fiziskās personas datiem, ja tās izdarīis personas datu apstrādes pārzinis vai operators ar nolūku atriebties, šantažēt vai mantkārības dēḷ, un šì panta trešajā daḷā paredzētā atbildība par personas datu apstrādes pārziṇa vai operatora, vai datu subjekta ietekmēšanu, pielietojot vardarbỉbu vai draudus vai l̦aunprātīgi izmantojot uzticību, vai ar viltu, lai veiktu nelikumīgas darbības ar fiziskās personas datiem, pēc šì darba autores domām, tiešā veidā uz "tiesībām tikt aizmirstam" neattiecas.

Turpretī, aplūkojot Civillikuma 1779. pantā paredzēto normu, kurā ir noteikts katra pienākums atlīdzināt zaudējumus, ko viņš ar savu darbību vai bezdarbību nodarīiis, personas datu aizsardzības jomā personas privātās dzīves aizskārums ir morāls kaitējums [21, 149]. Tiesu prakses apkopojuma "Morālā kaitējuma atlīdzināšana civillietās" 7.3. nodaḷā ir ietverti tiesu prakses piemēri par morālā kaitējuma atlīdzỉbas noteikšanu gadījumos, kad aizskarts personas privātums, gods un cieņa, kā arī prettiesiski izmantoti personas dati [15, 80-91]. Morālā kaitējuma apmērs tiesu prakses apkopojumā analizētajās civillietās ir no 71 līdz 7114 EUR. Lielākais morālā kaitējuma apmērs gadījumos, kad aizskarts personas privātums, gods un cieņa, kā arī prettiesiski izmantoti personas dati, vērojams publisko personu un politikā iesaistìto personu lietās, kurām, n̦emot vērā vin,u publisko dzīvi, nav "tiesību tikt aizmirstām", tāpēc morālā kaitējuma atlīdzība nepienāktos.

Piemēram, lietā Nr. SKC-1178/2012, kura potenciāli atbilst "tiesībām tikt aizmirstam", prasītājs O. G. cēla tiesā prasību pret komercsabiedrību, lūdzot, pirmkārt, uzdot atbildētājai dzēst informāciju savā datubāzē par prasītāja neesošajiem parādiem divām komercsabiedrībām un aizliegt atbildētājai izplatīt informāciju par prasītāja neesošajiem parādiem trešajām personām, otrkārt, piedzìt atlīdzību par morālo kaitējumu 2000 Ls. Prasītājam tika atteikta kredītkartes izsniegšana un kredita piešķiršana, jo atbildētājas parādnieku datubāzē bijis reǵistrēts prasītāja neapmaksāts parāds. Saskaṇā ar informāciju, kura ir pieejama globālajā tīmeklī, atbildētāja piedāvāja informāciju par prasitāja parādiem jebkurai personai pasaulē latviešu, krievu un angḷu valodā $[15,90]$.

Gan pirmās, gan apelācijas instances tiesa atzina, ka, nepārbaudot un savlaicīgi neizdarot labojumus fizisko personu kredītvēstures datubāzē, atbildētāja kā datu pārzinis FPDAL izpratnē nav nodrošinājusi FPDAL 10. panta pirmās daḷas 4. punktā noteikto pienākumu izpildi, tādējādi pieḷaujot prasītāja tiesību aizskārumu, kas izpaudies dažādu uzṇēmumu atteikumos sniegt pakalpojumus prasītājam. Apelācijas instances tiesa norādīja, ka atlīdzībai ir jābūt pietiekamai, lai veiktu prevencijas funkciju, proti, lai piespriestā summa atturētu atbildētāju un citas personas no līdzīga aizskāruma nodarišanas nākotnē, izvērtējot atbildētājas spēju dot šādu atlīdzību, kā arī ziṇu izplatǐšanas publiskumu un plašumu, aizskāruma smagumu attiecībā pret personu un sekas, ko radījusi godu un cieṇu aizskarošu ziṇu izplatīšana. Augstākā tiesa konstatēja, ka tikusi negatīvi ietekmēta prasīāja reputācija un prasītājs ticis personiski aizskarts, un kā taisnīgu un samērīgu atlīdzību par morālo kaitējumu noteikusi 426,86 EUR. Atbildētāja 
ar kasācijas sūdzību vērsās AT Senātā, taču tas, atzīstot, ka tiesa pamatoti ir konstatējusi prasītāja tiesību aizskārumu un noteikusi samērīgu atlīdzību, kasācijas sūdzību noraidija.

LR spēkā esošie tiesību akti un tiesu prakse saistībā ar personas datu aizsardzību, pēc šì raksta autores domām, neliecina, ka tie sekmēe "tiesības tikt aizmirstam" izpildīšanu, t. i., datu pārziņa aktīvu darbību, lai pildītu FPDAL 16. panta pirmajā dạ̣ā noteiktos pienākumus saistībā ar personas datu apstrādi, datu subjektam pieprasot, lai viṇa personas dati tiek papildināti vai izlaboti vai arī lai tiek pārtraukta to apstrāde, lai tie tiek iznīcināti, ja personas dati ir nepilnīgi, novecojuši, nepatiesi, pretlikumīgi apstrādāti vai arī tie vairs nav nepieciešami datu vākšanas mērḳim. Arī Satversmes 96. panta komentāros to autori atzīst, ka Latvijas likumdevējs vēl nav pieṇēmis vispārēju civiltiesiskās aizsardzības regulējumu privātuma aizskāruma gadījumā [16, 251].

N̦emot vērā iepriekšminēto, raksta autore uzskata, ka Vispārīgās datu aizsardzības regulas projekta VIII nodaḷā paredzētās personas tiesības uz kompensāciju un atbildība (77. pants), sankcijas (78. pants) un administratīvie sodi (79. pants) sekmēs "tiesību tikt aizmirstam" izpildī̌sanu Latvijā.

Aptaujāto uzṇēmumu pārstāvji norāda, ka tie ievēro un izpilda normatīvo aktu prasības neatkarīgi no tā, vai un kāds ir sankcijas lielums [11,12]. Piemēram, Draugiem.lv juridiskais padomnieks U. Pilāberts uzsver, ka "viena no SIA "Draugiem" vērtībām ir godīgums, kas nozīmē arī normatīvo aktu ievērošanu. Ar datiem saistīti jautājumi var būt ḷoti nozīmīgi jebkura uzṇēmuma reputācijai, kas var radīt smagākas sekas nekā Latvijas Administratīvo pārkāpumu kodeksā noteiktā sankcija, tāpēc sankcijas apmērs SIA "Draugiem" noteikti nav bijis kritērijs prasību ievērošanai (tas attiecas arī uz personas "tiesībām tikt aizmirstai")" [12].

Šeit būtu vietā ievērojamā Latvijas civiltiesību speciālista Vasilija Sinaiska atziṇa:

"[..] cik daudz strīdu neizcel̦as dažreiz ap vienu vai otru likuma pantu vienīgi aiz tā iemesla, ka šì panta iztulkojums sastāda pašmērḳi. Bet, attiecināts uz visu tiesību sistēmu kā normatīvi civiltiesisku sabiedrību, likuma pants tūdaḷ iegūst pienācīgu vietu un neapstrīdamu nozìmi." [13, 17]

Ja uzṇēmumi, ievērojot "tiesības tikt aizmirstam", spēj identificēt šīs tiesības un nodrošināt to izpildi pat situācijā, kad LR normatīvajos aktos pastāv nepilnības jautājumā par aizsardzības regulējumu privātuma aizskāruma gadījumā, tad ar tiem var lepoties.

Raksta nākamajā nodaḷā tiks aplūkots, kā valsts institūcijas spēj piemērot "tiesības tikt aizmirstam".

\section{“Tiesību tikt aizmirstam" izpratne un piemērošana}

Lai tiesību norma īstenotu savu regulatīvo funkciju, tās ir jāpiemēro: tiesību normu piemērotājam (piemēram, tiesai), izškirot kādu konkrētu dzīves gadījumu, jāatrod uz šo gadījumu attiecināma tiesību norma un ar tiesību normu piemērošanas aktu (piemēram, tiesas spriedumu) jānosaka un jākonkretizē šajā normā paredzētās tiesiskās sekas. 
Tiesību normas piemērošana ir valsts institūciju aktīva tiesiska darbība, lai piešķirtu tiesību subjektiem normas paredzētās tiesības un pienākumus, izraisot, grozot vai pārtraucot tiesiskās attiecības [13, 19].

Lai izprastu, vai un kā Latvijā tiek piemērotas "tiesības tikt aizmirstam”, šì darba tapšanas laikā Datu valsts inspekcijai, LR Tiesībsargam, Augstākajai tiesai un Tiesu administrācijai tika uzdots jautājums par vinunu "tiesību tikt aizmirstam" izpratni pēc 2014. gada 13. maijā EST sprieduma lietā C-131/12 Google Spain SL, Google Inc. pret Spānijas Datu aizsardzības aǵentūru.

Jāuzsver, ka LR Tiesībsarga dienas kārtībā jautājums par "tiesībām tikt aizmirstam" nav aplūkots [7]. Tādējādi var secināt, ka vismaz pagaidām šì valsts institūcija nav saṇēmusi sūdzības no privātpersonām par šo tiesību ievērošanu un izpildīšanu un pati arī nav izmantojusi savas Tiesībsarga likuma 13. panta 6. punktā noteiktās tiesības ierosināt pārbaudes lietu pēc savas iniciatĩvas, lai personu "tiesības tikt aizmirstām" tiktu ievērotas un izpildītas. Arī Augstākā tiesa nesniedza atbildi par "tiesību tikt aizmirstam" izpratni. Savukārt Tiesu administrācija sniedza atbildi, ka "tiesības tikt aizmirstam" ir tiesības prasìt interneta meklētājprogrammu pakalpojumu sniedzējiem dzēst no rezultātu saraksta, kas tiek atspoguḷots pēc meklējuma veikšanas, izmantojot personas vārdu, saites uz mājaslapām, kuras publicējušas trešās personas un kurās ir informācija saistībā ar šo personu, un ka Tiesu administrācija nenodrošina iespēju iegūt meklēšanas rezultātu sarakstu, meklēšanai izmantojot personas vārdu [8].

Datu valsts inspekcijas pārstāvis atzina, ka, izskatot iesniegtās sūdzības, inspekcija piemēro EST tiesas spriedumā minēto (tā atziṇas), kā tas minēts sprieduma tekstā, turklāt Datu valsts inspekcija piedalās Direktīvas 95/46/EK 29. panta darba grupas darbā un piemēro tās 2014. gada 26. novembrī apstiprinātās vadlīnijas Nr. WP225 [9].

2014. gadā Augstākā tiesa veica izmaiņas Tiesas kalendāra funkcionēšanas sistēmā, Tiesu administrācija veica izmaiņas tiesvedības gaitā (http://www.tiesas.lv/epakalpojumi/tiesvedibas-gaita) sniegtās informācijas apjomā, lai nodrošinātu personas datu aizsardzību. Tas liecina par to, ka pètījumā intervētās valsts iestādes līdz brīdim, kad tās saṇēma privātpersonu sūdzības, nav apzinājušas ar fizisko personu datu apstrādi saistītos potenciālos riskus. Nevar apgalvot, ka ar personas datu aizsardzību saistìtas līdzīgas problēmas pastāv arì citās valsts iestādēs, bet nevar paḷauties uz to, ka citās iestādēs ar personas datu apstrādi tiešsaistē saistìtu problēmu nav. Valsts iestādēm ir jāapzinās problēmas un jāveic atbilstoši personas datu aizsardzības pasākumi, paredzot izmaiṇas gan tiešsaistē publicēto datu apjomā, gan savās sistēmās, kur tiek publicēta informācija.

Šajā rakstā netiek plašāk aplūkots personas koda kā personas datu publiskošanas jautājums internetā; detalizēti par to var lasìt vairāku autoru rakstos $[1,19,20]$. Jāpiebilst, ka diskusija par personas koda publiskošanu tika sākta 2010. gadā, taču risinājums tika rasts 2014. gadā, kad Tieslietu ministrija piedāvāja un valdība akceptēja šādu risinājumu: 


\begin{abstract}
“Saskaṇā ar Informācijas atklātības likuma 5. panta otrās daḷas 4. punktu noteikt MK rīkojumam Nr. 305 "Par uzṇemšanu Latvijas pilsonībā naturalizācijas kārtībā" ierobežotas pieejamības statusu un nepublicēt šos rīkojumus www.mk.gov.lv un oficiālajā izdevumā. Savukārt, lai nodrošinātu sabiedrības tiesības uz informāciju par MK pieṇemtajiem lēmumiem, attiecīgās MK sēdes protokollēmumā varētu norādìt naturalizēto personu skaitu." [19]
\end{abstract}

Piedāvājot iepriekšminēto risinājumu, Tieslietu ministrija vērtēja, no vienas puses, personas vārda, uzvārda un personas koda publicēšanas mērḳi un sabiedrības ieguvumu no šo datu publicēšanas, no otras puses, personas tiesības uz savu personas datu aizsardzību. Jāuzsver, ka arī šìs situācijas risinājums ir meklējams kādas personas iesniegumā: 2014. gada 8. maijā Ministru prezidente izdeva rezolūciju, kurā Tieslietu ministrijai lūgts izvērtēt MK rīkojumu Nr. 305 par personas koda publicēšanu mājaslapā http://www.mk.gov.lv/ un oficiālajā izdevumā "Latvijas Vēstnesis" [19].

L. Velve mağistra darbā "Publiskie iepirkumi Latvijā un to problemātikas risinājumi" uzsvērusi, ka saistībā ar publisko iepirkumu publikācijām bieži ir sastopami pārkāpumi fizisko personu datu aizsardzībā, t. i., personas datu izpaušanā [22, 55]. Pārkāpumi izpaužas, gan ievadot personas datus saturošo informāciju Iepirkumu uzraudzības biroja iepirkumu publikāciju vadības sistēmā, gan arī gadījumos, kad pasūtītāji sadậa par publiskā iepirkuma uzvarētāju norāda personu identificējošu informāciju [22, 57].

Iepriekšminētie valsts institūciju pārkāpumi personas datu aizsardzības jomā, iespējams, pamato Latvijas iedzīvotāju, kuri neuzticas valsts iestādēm saistībā ar tiešsaistē atrodamiem datiem, lielo īpatsvaru: 2012. gadā bija 67\% šādu personu, 2013. gadā 64\% un 2014. gadā - 62\% [14]. Salīdzinot ar ES vidējo neuzticības rādītāju, ir vērojama pozitīva tendence - iedzīvotāju īpatsvars, kuri neuzticas valsts iestādēm saistībā ar tiešsaistē atrodamiem datiem, kopš 2012. gada samazinās, taču mums vēl ir tālu līdz zemākajam rādītājam, kāds ir Somijai (2014. gadā tas bija 25\%). Tātad personas datu apstrādē iesaistītajām LR valsts iestādēm, kā arī šo apstrādi uzraugošām valsts iestādēm vēl ir daudz jāizdara personas datu aizsardzības jomā, nevis jāpaḷaujas uz privātpersonu iniciatīvu.

Augstākās tiesas un Tiesu administrācijas pārstāvji norādīja, ka abu institūciju mājaslapās informācija tiek publicēta atbilstoši likuma "Par tiesu varu" $3 .{ }^{1}$ nodaḷu "Informācijas pieejamība" un MK 2009. gada 10. februāra noteikumiem Nr. 123 "Noteikumi par tiesu informācijas publicēšanu mājaslapā internetā un tiesu nolēmumu apstrādi pirms to izsniegšanas". Aplūkojot abus normatīvos aktus, netika atrasta informācija par termiṇiem, kuros Tiesu informatīvā sistēmā esošie personas dati ir pieejami tiešsaistē. Tātad personas datu aizsardzība, ievērojot "integrētās privātuma aizsardzības" (privacy by design) principu [3], iepriekšminētajos normatīvajos aktos nav paredzēta. 


\section{Secinājumi un priekšlikumi}

Intervētie Latvijas uzṇēmumi un valsts institūcijas ievēro personas "tiesības tikt aizmirstai" un pēc datu subjekta pieprasijuma, pamatojoties uz FPDAL 16. panta pirmajā daḷā noteikto, personas datus izlabo, pārtrauc to apstrādi vai iznīcina tos. Taču, analizējot intervēto valsts institūciju praksi saistībā ar fizisko personu datu apstrādi, var secināt, ka problēma ir daudz dzilāka nekā "tiesību tikt aizmirstam" ievērošana, jo uzskatāmi ir pārkāptas personas tiesības uz datu aizsardzību un tātad arī netiek ievērotas konstitucionālajā līmenī nostiprinātās personas tiesības uz privātās dzìves neaizskaramību. No vienas puses, ir logiiski, ka "tiesības tikt aizmirstam" tiek ievērotas tikai pēc privātpersonas pieteikuma. No otras puses, persona var pat nezināt, ka tās dati tiek apstrādāti un ir publiski pieejami tiešsaistē, tāpēc arī nelūgt, lai datu pārzinis pārtrauc to apstrādi, pamatojot savu lūgumu ar FPDAL 16. panta pirmās daḷas otrajā teikumā noteiktajiem iemesliem.

Internets ir atvērta tehniska platforma, un, tiklīdz dati ir publiskoti, tajā nevar kontrolēt to turpmāku izplatî̌šnu. Tāpēc valstij ir jāspēj ne tikai nodrošināt "tiesības tikt aizmirstam" un dzēst personas datus pamatota pieprasījuma gadījumā, bet arī nepielaut personas datu publicēšanu plašākā apjomā, nekā tas ir nepieciešams, lai sasniegtu legitīmu mērḳi. Tas tāpēc, ka, pamatojoties uz FPDAL 16. panta pirmajā dạ̣ā noteikto, datu pārziņa pienākums ir ne tikai pašam nekavējoties novērst šo pārkāpumu, bet arī paziṇot par to trešajām personām, kas iepriekš ir saṇēmušas apstrādātos datus. Pēc Eiropas Parlamenta un Padomes Vispārīgās datu aizsardzības regulas parakstī̌anas, pamatojoties uz šīs regulas 17. panta otro daḷu, datu pārzinis atbildēs arī par to, lai saites uz šiem personas datiem vai šo datu kopijām, vai atveidojumiem dzēš arī trešās personas. Ši papildu pienākuma ievērošana varētu prasīt lielus laika, cilvēku un materiālos resursus, ja atbilstošā līmenī netiek nodrošināta personas datu aizsardzỉba.

Iedzīvotāju neuzticēšanās iestādēm par tiešsaistē atrodamiem datiem ir samērā augsta. Uzticēšanās trūkuma dēḷ iedzīvotāji var neizmantot jaunus pakalpojumus, tostarp arī publiskos e-pārvaldības pakalpojumus, tāpēc publiskais sektors nevarēs gūt labumu no savu pakalpojumu digitalizācijas. Tādējādi var tikt kavēta ekonomikas izaugsme.

FPDAL 16. panta regulējums izsmeḷoši nosaka privātpersonas "tiesības tikt aizmirstai". Autore uzskata, ka šajā pantā nav nepieciešams atsevišḳi izdalīt "tiesības tikt aizmirstam", jo tajā ir regulētas arī citas datu subjekta tiesības. Taču, lai personas sāktu izmantot savas "tiesības tikt aizmirstām" un šīs tiesības tiktu ievērotas, ir nepieciešama sabiedrības izglītošana. Latvijas iedzīvotāji nav pietiekami informēti par savām "tiesībām tikt aizmirstiem". Fizisko personu (potenciālo datu subjektu) informēšanu sakarā ar fizisko personu datu aizsardzības pasākumiem būtu jāveic gan Datu valsts inspekcijai, gan LR Tiesībsargam. Savukārt Datu valsts inspekcijai būtu jāveic juridisko personu (potenciālo datu apstrādātāju) informēšanas pasākumi. Ja sabiedrība netiks informēta un negūs izpratni par "tiesībām tikt aizmirstam", tās netiks izmantotas un datu pārzinim neradīsies pienākums tās ievērot, kaut arī tas, ka tiešsaistē ir pieejami personas dati, var tikt uzskatìts par indivīda privātās dzīves aizskārumu. 
Lai veicinātu, ka datu pārzinis ievēro personas "tiesības tikt aizmirstai", likumdevējam būtu nepieciešams pien̦emt vispārēju civiltiesiskās aizsardzības regulējumu privātuma aizskāruma gadījumā, uz ko norādìts arī Satversmes 96. panta komentāros. Taču šì raksta autore uzskata, ka jautājumā par personas datu aizsardzību būtu nepieciešams precizēt FPDAL 32. pantā noteiktās personas tiesības saṇemt atbilstīgu atlīdzinājumu, ja, pārkāpjot ši likuma noteikumus, tai ir nodarīts kaitējums vai radīti zaudējumi. Tajā arī jāparedz, no kura šis atlīdzinājums būtu prasāms. Kā jau iepriekš tika minēts, pēc datu publicēšanas tiešsaistē to izplatišsana nav kontrolējama, tāpēc datu subjektam ir nepieciešams zināt, no kura viṇš / viṇa var prasit atlīdzinājumu: vai nu no datu pārziņa, kas sākotnēji publiskojis personas datus, vai no kāda cita.

Lai stiprinātu Latvijas iedzīvotāju uzticēšanos valsts iestādēm par tiešsaistē atrodamiem datiem un panāktu jaunu pakalpojumu, tostarp arī publisko e-pārvaldības pakalpojumu izmantošanu, kā arī sekmētu ekonomikas izaugsmi, Ministru prezidentam, pamatojoties uz Ministru kabineta kārtības ruḷ̦a XVI. daḷu "Ministru prezidenta rīkojumi un rezolūcijas un to izpildes nodrošināšana", saskaṇā ar 224. pantu jāuzdod visām ministrijām veikt vienu no šiem uzdevumiem:

1) izvērtēt ministriju pakḷautībā un pārraudzībā esošo iestāžu informāciju sistēmu tiešsaistē publicēto personas datu nepieciešamību un atbilstību personas datu aizsardzībai, kas noteikta FPDAL. Tāpat kā Tieslietu ministrijai, kas vērtēja vārda, uzvārda un personas koda publicēšanu tiešsaistē, ministrijām, analizējot attiecīgās informāciju sistēmas saistībā ar personas datu publicēšanu tiešsaistē, ir jāvērtē, no vienas puses, personas datu publicēšanas mērḳi un sabiedrības ieguvumi no šo datu publicēšanas, no otras puses, personas tiesības uz savu personas datu aizsardzību. Datu valsts inspekcijai ir jāuzñemas konsultēšanas funkcija;

2) novērtēt personas datu apstrādes atbilstību, kura ir noteikta FPDAL 26. panta otrajā prim daḷā, saskaṇā ar 2015. gada 15. maija MK noteikumiem Nr. 216 "Kārtỉba, kādā sagatavo un iesniedz personas datu apstrādes atbilstības novērtējumu" un ņemot par paraugu iepriekšminēto Tieslietu ministrijas vērtējumu.

Apzinoties faktu, ka pat ES dalībvalstu vidū patlaban nav vienprātības par principa "tiesïbas tikt aizmirstam" ieviešanas formu un ka regulas pien,emšana var aizn,emt vairākus gadus, Latvijai jau šobrīd savos normatīvajos aktos būtu nepieciešams ietvert principus jautājumā par "tiesībām tikt aizmirstam" un datu dzēšanu, kas paredzēti Eiropas Parlamenta un Padomes Vispārīgā datu aizsardzības regulā. Regulas 73. panta trešā daḷa atšçirībā no Direktīvas 95/46/EK 28. panta ceturtās daḷas piešķir tādām iestādēm kā LR Tiesībsargs neatkarīgi no datu subjekta sūdzības tiesības vērsties Datu valsts inspekcijā ar sūdzību, ka ir noticis personas datu aizsardzības pārkāpums. Vispārīgā datu aizsardzības regula nostiprinātu LR Tiesībsarga tiesības ierosināt pārbaudes lietu pēc savas iniciatīvas, kuras noteiktas Tiesībsarga likuma 13. panta 6. punktā. Tādējādi nevis atzinuma vai ieteikuma veidā, bet adresātam saistošā veidā tiktu panākta "tiesību tikt aizmirstam" izmantošana un arī to ievērošana. 
Normatīvajos aktos, kas regulē personas datu saturošas informācijas pieejamību tiešsaistē, ir jāiekḷauj nepārprotamas norādes uz termiṇiem, kuros šāda informācija ir pieejama tiešsaistē un pēc kuru beigām šāda informācija būtu dzēšama. Tādējādi tiktu ievērots "integrētās privātuma aizsardzības" (privacy by design) princips. Piemēram, likuma "Par tiesu varu" 3. nodaḷā "Informācijas pieejamība" un MK 2009. gada 10. februāra noteikumos Nr. 123 "Noteikumi par tiesu informācijas publicēšanu mājaslapā internetā un tiesu nolēmumu apstrādi pirms to izsniegšanas" būtu nepieciešams norādìt termiṇus, kuros Tiesu informatīvā sistēmā esošie personas dati ir pieejami tiešsaistē.

\section{Application and Understanding Problems of the "Right to be Forgotten" in Latvia}

\section{Abstract}

The "right to be forgotten" is a relatively new legal institution and the prerequisite for it are rapid technological developments and globalisation allowing information, including personal data and sensitive data, publicly available worldwide. The above mentioned requires the enhancement of the personal data protection.

The "right to be forgotten" had been brought up to date particularly in relation to the EU Court of Justice decision in case C-131/12 Google Spain SL and Google Inc. v Agencia Española de Protección de Datos (AEPD) and Mario Costeja González. The European Court of Human Rights is being faced with new concepts such as that of the "right to be forgotten".

The following conclusions are drawn when conducting the research: the remedies, liability and sanctions as provided in Latvian regulation only partially contribute to the compliance with the "right to be forgotten". The state institutions interviewed while carrying out this research are not aware of the potential risks concerning processing of personal data and make necessary changes in their data processing systems only in response to the individual/-s application. Therefore, to strengthen the trust of Latvian inhabitants in online data kept by public authorities and to enhance usage of e-government services, thus facilitating economic growth, the public authorities must review their existing practices regarding the processing of personal data and access online.

Keywords: the "right to be forgotten", personal data, processing of personal data, protection of personal data, Directive 95/46/EC, Personal Data Protection Law, General Data Protection Regulation. 


\section{Literatūra}

1. Apine, I. Cik personisks ir personas kods. Jurista Vārds, 32 (627), 10.08.2010.

2. Alexa. Top Sites in Latvia / Lithuania / Estonia. Iegūts no: www.alexa.com/topsites/countries/ LV; www.alexa.com/topsites/countries/LT; www.alexa.com/topsites/countries/EE

3. Eiropas Datu aizsardzības uzraudzītājs. Eiropas Datu aizsardzības uzraudzìtāja atzinums par Komisijas paziņojumu Eiropas Parlamentam, Padomei, Ekonomikas un sociālo lietu komitejai un Regionu komitejai - "Vispusīga pieeja personas datu aizsardzībai Eiropas Savienībā" (2011/C 181/01). Eiropas Savienības Oficiālais Vēstnesis, C 181/1, 22.6.2011.

4. Eurobarometer pētījums. Attieksme pret datu aizsardzību un elektronisko identitāti Eiropas Savienībā. 2011. gada jūnijs. Iegūts no: http://ec.europa.eu/public_opinion/archives/ebs/ ebs_359_fact_lv_lv.pdf; http://ec.europa.eu/public_opinion/archives/ebs/ebs_359_fact_lt_ lt.pdf; http://ec.europa.eu/public_opinion/archives/ebs/ebs_359_fact_ee_en.pdf

5. European Court of Human Rights. Case of Armoniene v. Lithuania No. 36919/02. Strasbourg 25/11/2008. Iegūts no: http://hudoc.echr.coe.int/sites/eng/pages/search.aspx?i=001-89823

6. Google transparency report. European privacy requests for search removals. Iegūts no: https:// www.google.com/transparencyreport/removals/europeprivacy/

7. Intervija - Bagātā, L. "Tiesības tikt aizmirstam” kā tiesības uz privātumu un to izpratne Latvijā (Latvijas Republikas Tiesībsarga birojs, Konsultante komunikācijas un starptautisko attiecību jautājumos). Rīga, 11.05.2015.

8. Intervija - Balševics, E. "Tiesības tikt aizmirstam" kā tiesības uz privātumu un to izpratne Latvijā (Tiesu administrācija, Direktors). Rīga, 12.05.2015.

9. Intervija - Datu valsts inspekcija. "Tiesības tikt aizmirstam" kā tiesības uz privātumu un to izpratne Latvijā. Rīga, 07.05.2015

10. Intervija - Kataja, B. "Tiesības tikt aizmirstam" kā tiesības uz privātumu un to izpratne Latvijā (Augstākās tiesas Komunikācijas nodaḷa). Rīga, 29.04.2015.

11. Intervija - Lunde, Z. "Tiesības tikt aizmirstam" kā tiesības uz privātumu un to izpratne Latvijā. (SIA “TV NET”, Galvenā redaktore). Rìga, 13.05.2015.

12. Intervija - Pilābers, U. "Tiesības tikt aizmirstam" kā tiesības uz privātumu un to izpratne Latvijā. (SIA “Draugiem”, Juridiskais padomnieks). Rīga, 28.04.2015.

13. Juridiskās metodes pamati: 11 soḷi tiesību normu piemērošanā: Rakstu krājums. Dr. hab. iur. prof. Meḷ kiša E. zinātniskajā redakcijā. Rīga: Latvijas Universitāte, 2003, 250 lpp.

14. Kinis, U. "Cyber-Strategic" strategic approach on cybercrime. Future challenges in tracking online criminology. CEPO conference. Latvian Presidency of the Council of the European Union. Rīga, 24 March, 2015.

15. Latvijas Republikas Augstākā tiesa. Morālā kaitējuma atlīdzināšana civillietās. Tiesu prakses apkopojums. Rīga, 2014. Iegūts no: http://at.gov.lv/lv/judikatura/tiesu-prakses-apkopojumi/ civiltiesibas/

16. Latvijas Republikas Satversmes komentāri. VIII nodal̦a. Cilvēka pamattiesības. Autoru kolektīvs prof. R. Baloža zinātniskā vadībā. Rīga: Latvijas Vēstnesis, 2011, 864 lpp.

17. Latvijas Republikas Tiesībsargs. Tiesībsarga biroja darbỉbas jomas. Iegūts no: http://www. tiesibsargs.lv/par-mums/tiesibsarga-birojs/darbibas-jomas 
18. Latvijas Republikas Tiesībsargs. Pieteikums par Uzturlidzekḷ garantiju fonda likuma 5.1 panta atbilstību Satversmes 96. panta vārdiem "Ikvienam ir tiesības uz privātās dzìves (..) neaizskaramību” 2014. gada 30. decembrī. Iegūts no: http://www.tiesibsargs.lv/files/content/ Satversmes_tiesai_pieteikums_UGF_paradnieku_publiskosana_30122014.pdf

19. Matule, S. Atrasts risinājums personas kodu publiskošanas jautājumā. Jurista Vārds, 32 (634), 19.08.2014.

20. Rone, D., Jarinovska, K., Lỉbiņa-Egnere, I., Litvins, G., Ruķers, M., Zeile, O., Austere, L. Personas koda lietošana publiski pieejamos dokumentos. Jurista Vārds, 32 (627), 10.08.2010.

21. Ruḳers, M. Personas datu tiesiskā aizsardzība. Rīga: Biznesa augstskola Turība, 2000, 189 lpp.

22. Velve, L. Publiskie iepirkumi Latvijā un to problemātikas risinājumi: maǵistra darbs. Rīgas Stradiṇa universitātes Juridiskā fakultāte, Rīga, 2014, 106 lpp.

23. Vilka, K. Bērna tiesību uz privāto dzīvi aizsardzība interneta vidē. Starptautiskā zinātniski praktiskā konference "Transformācijas process tiesībās, reǵionālajā ekonomikā un ekonomiskajā politikā” (2012, Rīga, Latvija). Rīga: Baltijas Starptautiskā akadēmija, 2013, 164.-171. lpp. 